обыкновенный (Ficus carica L.) из семейства Тутовые (Moraceae Link), миндаль обыкновенный (Amygdalus communis L.) из семейства Розовые (Rosaceae Juss.), хурма виргинская (Diospyros virginiana L.) из семейства Эбеновые (Ebenaceae Guer.).

На примере Полтавской обл., природно-климатические условия которой являются типичными для физикогеографической зоны Лесостепи Украины, показано, что в отдельные годы в зимний период совокупное действие низких отрицательных температур воздуха и ветра может быть критическим из учета их морозоустойчивости.

Ключевые слова: Лесостепь Украины, интродукция, субтропические виды, совокупное действие мороза и ветра.

Krasovsky Volodymyr, Chernyak Taisiya. Risks of Cultivation of Subtropical Fruit Crops in the Foreststeppe Zone of Ukraine. Recent years spreading of some subtropical fruit crops on the plots caused with introduction activity of botanical garden, plays an important role for increasing of fruit species in the forest-steppe zone of Ukraine. They are Asimina triloba (L.) Dunal, belonging to the family Annonaceae DC., Punica granatum L., belonging to the family Lythraceae J. St-Hil., Zizyphus jujuba Mill., belonging to the family Rhamnaceae R. Br., Ficus carica (L.) belonging to the family mulberry Moraceae Link, Amygdalus communis L., belonging to the family Rosaceae Juss., Diospyros virginiana L., belonging to the family Ebenaceae Guer.

It was taken Poltava region, which native climatic conditions are typological for physical and geographical zone of Ukrainian forest-steppe and observed that some years the effect of air low temperature during winter period can be dangerous.

Key words: the forest-steppe zone of Ukraine, introduction, subtropical species, the combined effect of frost and wind.

Стаття надійшла до редколегії 20.09.2016 р.

УДК 635.055:630.5:712.253(477.84)

\author{
Антоніна Ліснічук, \\ Руслана Панасенко, \\ Леонід Вериківський
}

\title{
Характеристика вікових дерев Кременецького ботанічного саду за кількісними та якісними ознаками
}

У ландшафтах парку Кременецького ботанічного саду зростає 93 екземпляри дерев 14 видів трьох категорій: потенційно вікові, вікові та багатовікові. Середні показники віку варіюють у межах 114-202 p. із максимальною позначкою 245 р., висоти дерев - від 19 до 34 м, діаметра крони - від 5 до 12 м, діаметра стовбура від 43, 9 до 98,7 см. Збереглися дерева, висаджені за часів Єзуїтського колегіуму та в період функціонування ботанічного саду в складі Вищої Волинської гімназії. За санітарним станом до першої категорії (без ознак ослаблення) віднесено 32 дерева (34,0 \%). Високоестетичні якості виявлено в 53 дерев (57, \%). Такі дерева мають природоохоронну, наукову, історичну, педагогічну, рекреаційну цінності, тому потребують невідкладних заходів щодо збереження та утримання.

Ключові слова: вікові дерева, вікові категорії, біометричні показники, санітарний та естетичний стани.

Постановка наукової проблеми та їі значення. Осередки культивованої дендрофлори на ВолиноПоділлі почали формуватися понад 500 років тому. Перші інтродукційні спроби мали стихійний або спонтанний характер без достатнього наукового обгрунтування. Важливими науковими інтродукційними осередками завжди були і є ботанічні сади. Кременецький ботанічний сад - один із найстаріших в Україні осередків природничої науки й інтродукції. Витоки ботанічного саду в Кременці сягають 1754 р., коли при Єзуїтському колегіумі закладено аптекарський сад. Після відкриття Вищої Волинської гімназії організовують власне ботанічний сад, який набуває статусу наукової й навчальноосвітньої установи та стає осередком культивованої дендрофлори на Волино-Поділлі.

На сьогодні історична частина Кременецького ботанічного саду називається «Старий парк» (згідно з Проектом організації території, 2006) і є складовою частиною експозиційної зони ботанічного саду та єдиною частиною старого Кременецького ботанічного саду, яка збереглася до наших днів. У ландшафтах парку зростають дерева поважного віку, які є історичною й культурною спадщиною.

(С) Ліснічук А., Панасенко Р., Вериківський Л., 2016 
Аналіз досліджень цісї проблеми. Історія створення ботанічного саду, його функціонування в складі Вищої Волинської гімназії, внесок щодо акліматизації та інтродукції деревних видів рослин висвітлено в наукових виданнях [3; 6; 7]. В основі роботи - власні результати дослідження насаджень вікової дендрофлори в парковій частині ботанічного саду.

Мета роботи - вияснити деякі історичні аспекти формування насаджень вікової дендрофлори «Старого парку», схарактеризувати їх сучасний стан, визначити перспективи використання та збереження.

Матеріал і методи. Обстеження деревних насаджень здійснювали маршрутно-візуальним методом. Під час польових вишукувань виконували біометричні виміри вікових деревних рослин парку й оцінювали їх екологічний та естетичний стани. При визначенні біометричних показників установлювали такі параметри: висота рослин (за допомогою висотоміра), діаметр стовбура на висоті 1,3 м за формулою, де Д - діаметр (см), $L$ - обхват стовбура (см), $\pi$ - число 3,14 , діаметр крони - за допомогою рулетки.

Орієнтовний вік дерев установлювали методом експертної оцінки, за діаметром і шляхом підрахунку річних кілець [1]. Розподіл деревних рослин за віковими категоріями здійснювали за 4-бальною шкалою [8].

Санітарний стан оцінювали за шкалою, наведеною в «Санітарних правилах в лісах України» [4]. Під час обстеження визначено стан кожного дерева: мертве (сухе), суховерхівкове, із сухими гілками (скелетними, боковими). Інші ознаки пошкодження дерев (дупла та плодові тіла труговиків, механічні пошкодження стовбура) фіксували, користуючись методикою, запропонованою T. Kowalski, A. Czekaj [10].

Естетичний стан вікових дерев оцінювали за шестибальною шкалою, пристосованою для оцінки вікових дерев в історичних насадженнях [9].

Отримані результати опрацьовували з допомогою ПК із використанням програм Microsoft Office World та Microsoft Office Excel, 2003, 2008.

Виклад основного матеріалу й обгрунтування отриманих результатів дослідження. У 1805 р., після підписання указу про створення Вищої Волинської гімназії, у Кременці приступають до організації ботанічного саду у форматі повноцінного науково-дослідницького й навчального об' єкта. За 1810-1816 pр. тут уперше інтродуковано понад 60 видів деревних і чагарникових рослин, серед них - такі види, як Juniperus virginiana L., Juglans cinerea L., Symphoricarpos albus (L.) Blake., Ginkgo biloba L. та ін.

На плані центральної частини міста Кременця початку XIX ст. вже чітко проглядається територія ботанічного саду із системою доріг і стежок. Його площа -8 моргів (1 морг - 0, 56 га), тобто майже 4,5 га [7, с. 35]. Якраз на цій території здійснюються перші посадки інтродукованих деревних рослин, а також дерев-аборигенів, частина з яких зростає тут до сьогодні.

«Старий парк» має площу 2,48 га. Парк розміщений на похилому схилі, частково огороджений муром, який спорудили ще в 1806 р. Характерні форми рельєфу - перепади висот 2-6 м та елементи мікрорельєфу антропогенного походження (виїмки, грунтові дороги зигзагоподібної форми, стежки, великі пні тощо). Деревний ярус парку представлено лісопарковими породами. Тут зростає 327 дерев різних порід, віку й бонітету. Особливе місце серед насаджень парку займають вікові дерева.

За даними інвентаризації 2015 р., у парку зростає 91 дерево віком від 107 до 245 років та два дерева, вік яких наближається до 100 років. Середні показники віку варіюють у межах 114-202 років, висоти дерев - від 19 до 34 м (мінімальне значення - 8 м, максимальне - 36 м), діаметра крони - від 5 до 12 м (мінімум - 4 м, максимум - 15 м), діаметра стовбура - від 43, 9 до 98,7 см (мінімум - 21 см, максимум - 126 см), (табл.1). Одинадцять дерев $є$ безверхівковими.

Таблиия 1

\section{Середні значення віку та морфометричних показників вікових дерев} Кременецького ботанічного саду

\begin{tabular}{|c|c|c|c|c|c|}
\hline \multirow{2}{*}{$\begin{array}{c}\text { № } \\
\text { 3/II }\end{array}$} & \multirow{2}{*}{ Назва виду } & \multirow[t]{2}{*}{ Висота, $\boldsymbol{\mu}$} & \multicolumn{2}{|c|}{ Діаметр } & \multirow[t]{2}{*}{ Вік } \\
\hline & & & крони, $\boldsymbol{M}$ & стовбура, $c$ м & \\
\hline 1 & 2 & 3 & 4 & 5 & 6 \\
\hline 1 & Acer campestre L. & $19 \pm 0,0$ & $9,0 \pm 0,0$ & $44,6 \pm 0,0$ & $115 \pm 0,0$ \\
\hline 2 & Acer platanoides L. & $20,3 \pm 5,2$ & $8,1 \pm 1,9$ & $65,9 \pm 16,6$ & $149 \pm 26,6$ \\
\hline
\end{tabular}


РОЗДІЛ І. Ботаніка. 12, 2016

Закінчення таблииі 1

\begin{tabular}{|c|l|c|c|c|c|}
\hline $\mathbf{1}$ & $\mathbf{2}$ & $\mathbf{3}$ & $\mathbf{4}$ & $\mathbf{5}$ & $\mathbf{6}$ \\
\hline 3 & Acer pseudoplatanus L. & $21,6 \pm 4,9$ & $8,4 \pm 1,9$ & $77,8 \pm 19,5$ & $168 \pm 31,2$ \\
\hline 4 & Aesculus hippocastanum L. & $26,0 \pm 0,0$ & $10,0 \pm 0,0$ & $95,5 \pm 0,0$ & $197 \pm 0,0$ \\
\hline 5 & Betula pendula Roth. & $22,0 \pm 0,0$ & $5,0 \pm 0,0$ & $43,9 \pm 0,0$ & $114 \pm 0,0$ \\
\hline 6 & Carpinus betulus L. & $19,5 \pm 3,3$ & $10,0 \pm 1,3$ & $80,3 \pm 20,6$ & $173 \pm 33,1$ \\
\hline 7 & Fagus sylvatica L. & $22,1 \pm 5,6$ & $11,0 \pm 2,3$ & $78,4 \pm 21,2$ & $160 \pm 40,0$ \\
\hline 8 & Fraxinus excelsior L. & $23,7 \pm 9,0$ & $7,8 \pm 2,8$ & $86,0 \pm 14,2$ & $182 \pm 22,7$ \\
\hline 9 & Larix decidua Mill. & $34,0 \pm 0,0$ & $9,0 \pm 0,0$ & $93,3 \pm 0,0$ & $193 \pm 0,0$ \\
\hline 10 & Picea abies (L.) Karst. & $22,0 \pm 0,0$ & $6,0 \pm 0,0$ & $46,2 \pm 0,0$ & $118 \pm 0,0$ \\
\hline 11 & Pinus sylvestris L. & $30,5 \pm 2,5$ & $7,0 \pm 0,0$ & $60,8 \pm 10,5$ & $141 \pm 16,8$ \\
\hline 12 & Populus alba L. & $27,0 \pm 0,0$ & $12,0 \pm 0,0$ & $98,7 \pm 0,0$ & $202 \pm 0,0$ \\
\hline 13 & Tilia cordata Mill. & $22,1 \pm 1,6$ & $7,7 \pm 1,6$ & $60,2 \pm 20,8$ & $140 \pm 33,3$ \\
\hline 14 & Ulmus carpinifolia Rupp. ex G. Suckow. & $22,0 \pm 0,0$ & $7,0 \pm 0,0$ & $69,4 \pm 0,0$ & $155 \pm 0,0$ \\
\hline
\end{tabular}

Таксономічна структура вікових деревних насаджень нараховує 14 видів. Одиничними екземплярами зростають Acer campestre L., Aesculus hippocastanum L., Betula pendula Roth., Larix decidua Mill., Picea abies (L.) Karst., Populus alba L., Ulmus carpinifolia Rupp. ex G. Suckow. Найбільшу кількісну участь (46 екземплярів) має Fraxinus excelsior L. Кількісний склад решти видів варіює від двох до 13 екземплярів.

Дерев, вік яких перевищує 200 років, у парку 20. Це Fraxinus excelsior, тринадцять екземплярів віком 200-245 років, Fagus sylvatica L., два екземпляри віком 228-229 років, Acer pseudoplatanus L., два екземпляри віком 216 та 223 роки та по одному екземпляру представлені Populus alba - 202 роки, Tilia cordata Mill. - 203 роки, Carpinus betulus L. - 224 роки.

Інтродуцентів тут лише два види, це натуралізований екзот Aesculus hippocastanum L. та Larix decidua Mill., яка вже понад 200 років є об'єктом лісокультурної діяльності. Їх вік наближається до 200 років.

Досліджувані дерева належать до трьох вікових категорій: потенційно-вікові $(2,2 \%)$, вік яких наближається до 100 років, вікові (77,4 \%) - від 100 до 200 років, багатовікові $(20,4 \%)$ - понад 200 років.

Ураховуючи вік досліджуваних дерев, можна припустити, що окремі з них були висаджені ще за часів Єзуїтського колегіуму та особливої академічної школи, яка діяла в його стінах. Із часу функціонування ботанічного саду як складової частини навчального закладу (1806-1847 рр.) збереглося 41 дерево. Інші, імовірно, висаджували в 1921-1939 рр., коли в стінах колишнього колегіуму функціонували Кременецький ліцей з учительською семінарією та гімназією ім. Чацького.

За санітарним станом до першої категорії (без ознак ослаблення) віднесено 32 дерева (34,4 \%). Майже 65,6 \% деревостану пошкоджено різними хворобами, шкідниками, рослинами-паразитами, грибками. Так ураження омелою зафіксовано в 11 дерев (11,9\%). Мінуюча міль уражає Aesculus hippocastanum. На деяких деревах роду Acer L. розвивається чорна плямистість листя. На стовбурах Fagus sylvatica та Fraxinus excelsior наявні плодові тіла трутовиків. У трьох дерев Acer pseudoplatanus виявлено сильне пошкодження омелою, сухі скелетні гілки та в одного дерева - зламану верхівку. У старому парку ботанічного саду 24 дерева Fraxinus excelsior охоплено всиханням. У них зафіксовано сухі гілки й верхівки, унаслідок буревіїв у деяких зламано стовбури. Досить значною є кількість дерев, уражених стовбуровими гнилями, про що свідчить наявність дупел і плодових тіл трутовиків. У лісах заходу України простежено всихання Fraxinus excelsior, які викликані хворобами різної етіології. Особливу небезпеку становить поширення нового небезпечного збудника некрозу Hymenoscyphus pseudoalbidus, який у Європі призводить до швидкого відмирання дерев ясена різного віку. Поширення хвороби набуває характеру епіфітотії й становить значну загрозу для лісів та зелених насаджень з участю ясена звичайного [2]. У нашому випадку достовірно діагностувати причини всихання ми не можемо через відсутність відповідних служб і лабораторії. У минулому, згідно з Правилами утримання зелених насаджень у населених пунктах України, аварійним деревам Fraxinus excelsior й Acer platanoides L., які становили загрозу для людей і навколишніх будівель, проведено низку заходів для зниження крони, це сприяло пробудженню сплячих бруньок. Однак у чотирьох дерев Fraxinus excelsior відновлення крони не відбулося. 
За результатами обстеження естетичного стану три дерева $(3,1 \%)$ оцінено в 1 бал, 33 - $(35,5 \%)-$ 3 балами, $17(18,3 \%)$ - 4, 26 (28,0 \%) - 5 і $14(15,1 \%)$ - 6 балами, двома балами не оцінено жодного дерева. Отже, високоестетичні якості виявлено в 53 дерев (57 \%). Естетика стародавніх дерев $€$ загальновизнаною [5; 9], однак хвороби, шкідники, антропогенний фактор та час негативно вплинули на загальний естетичний стан 40 дерев $(43,0 \%)$.

Територія старого парку входить до переліку ділянок проектних розробок і підлягає частковій реконструкції, оскільки час і тривалий занепад ботсаду відіграли свою негативну роль на збереженні на функціонуванні різних ділянок парку. Для покращення естетики парку науковими співробітниками саду розроблено рекомендації з облаштування паркових композицій таким чином, щоб зберегти функціональний зміст і головну композиційну ідею історичного об'єкта. Насамперед, потребують дбайливого ставлення вікові дерева. Потрібно забезпечити індивідуальний захист кожного дерева, провести лікування уражених дерев, укріпити скелетні гілки. До дерев, які мають сухі верхівки та багато всихаючих гілок, застосувати полярдирування як один зі способів їх омолодження. Доцільно розробити програму екологічного моніторингу стану насаджень старого парку. Парк розміщений у межах експозиційної зони, $є$ одним із найбільш відвідуваних об'єктів, у зв'язку з чим зазнає інтенсивного антропогенного навантаження, тому потрібно провести експертизу на безпечність, по можливості, відновити історичні ландшафтні композиції та алеї. Для збереження дерев потрібне встановлення інформаційних аншлагів із вказівкою таксономічного положення, природного ареалу, біоморфологічної характеристики, віку, природної й історичної цінності. Важливого значення при цьому набуває популяризація матеріалів про історію ботанічного саду, зокрема про вікові дерева в різноманітних засобах масової інформації, завдяки цьому привертатиметься увага до їх охорони та збереження.

Висновки та перспективи подальших досліджень. Вікові дерева, які зростають на території Кременецького ботанічного саду, у старому парку представлені трьома віковими категоріями, характеризуються унікальними морфометричними показниками, але зазнають впливу різних негативних факторів і значного антропогенного навантаження, що негативно впливає на їхній санітарний та естетичний стан. Домінуючи в паркових насадженнях, надають їм естетичної привабливості й поєднують усі рослини в єдину композицію, однак понад половина з них потребує невідкладних заходів щодо збереження та утримання. Такі дерева мають природоохоронну, наукову, історичну, педагогічну, рекреаційну цінності.

\section{Джерела та література}

1. Исиков В. П. Методы исследований лесных экосистем Крыма / В. П. Исиков, Ю. В. Плугатарь, В. П. Коба. Симерополь : ИТ «Ариал». - 2014. - 252 с.

2. Мацях І. П. Всихання ясена звичайного (Fraxinus excelsior L.) на заході Украини / І. П. Мацях, В. А. Кремарець // Науковий вісник НЛТУ України. - 2014. - Вип. 24.7. - С. 67-74.

3. Мельник В. І. Сад Волинських Афін. Ботанічна наука та освіта у Волинській гімназії - Кременецькому ліцеї (1806-1832) / В. І. Мельник. - К. : Фітосоціоцентр, 2008. - 28 с.

4. Санітарні правила в лісах України // Постанова Кабінету Міністрів України від 27 липня 1995 р. - № 555 . - К., 1995. $-16 \mathrm{c}$.

5. Стародавні дерева України: ресстр-довідник / П. І. Гриник, М. П. Стеценко, С. Л. Снайдер та ін. - К. : Логос, 2010. $-143 \mathrm{c}$.

6. Черняк В. М. Культивована дендрофлора Волино-Поділля, перспективи іï використання та збагачення / В. М. Черняк. - Тернопіль : Вид-во ТНПУ, 2004. - 264 с.

7. Чопик В. І. Професор Університету св. Володимира Віллібальд Бессер та його учні - перші дослідники флори України (до 225-річчя з дня народження) / В. І. Чопик, О. К. Галаган. - Кременець, 2010. - 48 с.

8. Шлапак В. П. Біометричні показники вікових деревних рослин дендропарку «Софіївка» та їх розподіл за віковими категоріями / В. П. Шлапак, Г. І. Музика, В. А. Вітенко, Л. І. Марно // Науковий вісник НЛТУ України. - 2011. - Вип. 21.5. - С. 8-15.

9. Шлапак В. П. Методи оцінки естетичного стану вікових деревних насаджень історичної частини Національного дендропарку «Софіївка» НАН України / В. П. Шлапак, Г. І. Музика, В. А. Вітенко, Л. І. Марно, Н. О. Гончар // Науковий вісник НЛТУ України : зб. наук.-техн. пр. - Львів : РВВ НЛТУ України. - 2010. - Вип. 20. 6. C. 8-13.

10. Kowalski T. Symptomy chorobowe i grzyby na zamierających jesionach (Fraxinus excelsiorL.) w drzewostanach Nadleśnictwa Staszòw / T. Kowalski, A. Czekaj // Leśne Prace Badawcze (Forest Research Papers), 2010. - Vol. 71 (4). P. 357-368. 
Лисничук Антонина, Панасенко Руслана, Вериковский Леонид. Характеристика возрастных деревьев Кременецкого ботанического сада по количественным и качественным признакам. На территории парка, с которого берет начало Кременецкий ботанический сад, растет 93 экземпляра деревьев 14 видов трех категорий: потенциально возрастные, возрастные и многовековые. Средние показатели возраста варьируют в пределах от 114 до 202 лет с максимальной отметкой 245 лет, высоты деревьев от 19 до 34 м, диаметра кроны от 5 до 12 м, диаметра ствола - от 43, 9 до 98,7 см. Показатели высоты деревьев варьируют в пределах 21-36 м, диаметра кроны - 4-15 м, диаметра ствола - 21-126 см. Деревья высажены во времена Иезуитского коллегиума, особой академической школы, в период функционирования ботанического сада как составной части Волынской гимназии и Кременецкого лицея с учительской семинарией и гимназией им. Чацкого. За санитарным состоянием к первой категории (без признаков ослабления) отнесены 32 дерева $(34,0 \%)$. Высокоэстетичными качествами обладают 53 дерева $(57,0 \%)$. Такие деревья имеют природоохранную, научную, историческую, педагогическую, рекреационную ценности, поэтому нуждаются в неотложных мерах по сохранению и содержанию.

Ключевые слова: возрастные деревья, возрастные категории, морфометрические показатели, санитарное и эстетическое состояния.

Lisnichuk Antonina, Panasenko Ryslana, Verykivskyi Leonid. Characteristic of the old Trees in Kremenets Botanical Garden According to Their Quantitative and Qualitative Criteria. Assessment of the venerable dendroflora condition on kremenets botanical garden park territory. 93 copies of 14 species of trees grow at present on the park territory from which Kremenets botanical garden takes its beginning. They are of threecategories: potentially oldaged,old-aged and centuries-old. The average age rangesfrom 114 to 202 years with a peak of 245 years, the tree height is from 19 to 34 meters, diameter of the crown varies from 5 to $12 \mathrm{~m}$, trunk diameter - from 43,9 to $98,7 \mathrm{~cm}$.

Height of trees is from 21 to $36 \mathrm{~m}$, diameter of crown ranges from 4 to $15 \mathrm{~m}$, diameter of trunk extends from 21 to $126 \mathrm{~cm}$. The trees were planted in the days of the Jesuit collegium, a special academic school, in the period of the botanical garden functioning as a component part of theVolyn High school and Kremenets Lyceum with teachers'seminary and High School named after Chatsky. The sanitary condition of the first category (with no signs of weakening) includes 32 trees $(34,0 \%)$. Highly aesthetic features were testified to 53,0 trees $(57,0 \%)$. These trees have environmental, scientific, historical, educational, recreational values, therefore taking urgent measures for their conservation and maintenance is needed.

Key words: ancient trees, age categories, biometric indicators, sanitary and aesthetic conditions.

Стаття надійшла до редколегії 29.09.2016 р.

УДК 581.1:58.02

\section{Лариса Сергєєва,} Лариса Броннікова

\section{Пролін-опосередковані реакції тютюну на дію засолення}

Предметом роботи стало порівнянне дослідження реакцій тютюну за дії летального засолення та ролі вільного проліну в реалізації солестійкості.

Методом клітинної селекції з використанням летальних для клітинних культур доз катіонів $\mathrm{Ba}^{2+}$ отримано стійкі клітинні лінії тютюну. Із них отримано регенеранти R0, а також насіннєві покоління R1, R2. Клітинні лінії й рослини R0, R1 та R2 вирізнялися стійкісттю до модельованого летального сольового стресу. Порівнювали реакції, спряжені з підвищенням рівня вільного проліну, в експериментально отриманних рослин і вихідних рослин тютюну, який $є$ типовим глікофітом. Рослини R0 культивували in vitro протягом 35 діб у присутності 20,0 г/л солей морської води, рослини R1, R2 тестували у водній культурі 10 діб, додаючи 25,0 г/л тієї ж речовини.

Відзначали протилежні реакції рослин тютюну у відповідь на дію засолення: контрольні рослини гинули, а експериментальні варіанти стабілізували свій метаболізм, що проявлялось у збереженні синтезу білка. Водночас у всіх рослинах зростав уміст вільного проліну. Однак акумуляція цієї амінокислоти в експериментальних варіантах була наслідком підвищення іiі синтезу, тоді як пролін у контрольних рослинах утворювався при деградації клітинних білкових компартментів. Отже, абсолютне значення вмісту вільного проліну не може бути гарантованим показником солестійкості, потрібно оцінювати динаміку його змін.

Ключові слова: тютюн, клітинна селекція катіони барію, засолення, стійкість, пролін.

(ㄱ Сергєєва Л., Броннікова Л., 2016 